УДК 341.64:341.231.14

\title{
PILOT AND QUASI-PILOT JUDGMENTS OF THE EUROPEAN COURT OF HUMAN RIGHTS: ENSURING ENHANCED PROTECTION OF HUMAN RIGHTS
}

\author{
Y. Sushko \\ Expert of the Council of Europe project \\ "Continued Support to the Criminal Justice Reform in Ukraine», \\ e-mail:sushko12@gmail.com
}

Following the enlargement of the Council of Europe during the 1990s, the workload of the European Court of Human Rights multiplied, with thousands of cases coming from the new Member States. The Court has been dealing with mass litigation arising out of diverse structural and complex problems in the Contracting States for nearly two decades. These human rights deficiencies in the Contracting States give rise to constantly increasing numbers of applications to the Court. The Court has developed new remedial powers and mechanisms that significantly change the architecture of the Convention system regarding the implementation of the Court's judgments. A relatively new competence for the Court is to initiate a pilot and quasi-pilot judgment procedure. The main category of judgments referring to Article 46 of the Convention is composed of pilot judgments. For the present days, the distinction between pilot and quasi-pilot judgment is not really clear. The Court is overloaded with cases, mostly of a repetitive nature and in order to maintain the system's effectiveness, Member States have been urged to execute judgments more rapidly. The pilot judgments procedure was a response to the structural human rights problems in Contracting States triggering repetitive applications and to several Contracting States' reluctance to solve those problems on the national level.

Keywords: execution of judgments, clone cases, complex and systemic problems

DOI: http://dx.doi.org/10.30970/vla.2019.68.050

Since the construction of the Conventional system the Committee of Ministers of the Council of Europe (hereinafter «the CM») was considered to be the only organ of the Council of Europe (hereinafter «the CoE») responsible for the execution of judgments of the European Court of Human Rights (hereinafter «the Court»). The Court was only attributed a repressive, supplementary and interpretative role rather than an active, preventive and enforcing one. The practice of the CM has been extensive and its working methods have been continually developed far beyond the expectations of the drafters of Article 46(2) of the Convention so to cope with contemporary realities and to maximize the impact of the Convention at the national level [13, p. 945].

Nevertheless, since entry into force of the 11th of Protocol this clear division of responsibility has begun to change. Despite its restricted role in the Convention system, confined to the election of judges of the Court, the Parliamentary Assembly of the Council of Europe (hereinafter «the PACE») has been progressively involved in the execution of the Court judgments, exercising a sort of «parliamentary control" over the relevant activities of the CM [7, p. 30]. The traditional institutional equilibrium, provided for in the Convention, has gradually changed. The density of today's Court's practice under Article 46 of the Convention seems to put into question the traditional «separation of powers» between the judiciary and «executive» and to contribute to a «jurisdictionalization» of the execution process [18, p. 286].

(C) Sushko Y., 2019 
Y. Sushko

ISSN 0136-8168. Вісник Львівського університету. Серія юридична. 2019. Випуск 68

The Court, as an international tribunal, should be allowed some margin of manoeuvre within the Convention system for defining its role with respect to remedies. In support of this argument, reference could be made to three provisions in the Convention that could serve as a legal basis for indicating or prescribing remedial measures - Article 19 (concerning the role of the Court to ensure respect for the Convention), Article 32 (pursuant to which the Court is competent to rule upon its own jurisdiction where this question is disputed), and Article 46 (binding force and execution of judgments). These provisions, in conjunction with subsequent State practice, which showed that the CM supported the Court's remedial approach, constituted a sufficient legal basis to conclude that the Court was competent to be prescriptive. In addition, in Manushaqe Puto and others v. Albania, nos. 604/07, 43628/07, 46684/07 and 34770/09, paras. 102-106 case, the Court had occasion to point out that, under Article 19 of the Convention, it had jurisdiction to «ensure» the observance of the engagements undertaken by States in the Convention. In other words - and in accordance with the «implied powers» doctrine - if it finds it necessary to indicate individual or general measures to discharge this task, the Court has the power to do so.

Consequently, the Convention originally foresaw a supplementary role for the Court in the implementation process, with its major function being to interpret the Convention. The Court has meanwhile adopted the role of triggering and authoritatively indicating specific steps of implementation, thereby usurping the primary task in the implementation process and relegating the $\mathrm{CM}$ and the Member States to supplementary positions [11, p. 10].

According to the Court statistics many of the about 57,350 cases pending before the Court are so-called "repetitive cases» [1, p. 10], which derive from a common dysfunction at the national level.

Judge Pinto de Albuquerque in his concurring opinion in case Fabris v. France, no. 16574/08, 07.02.2013 stated that: «the Court's judgments are no longer purely declaratory, but prescriptive. In view of the increasingly prescriptive nature of the Court's judgments, and consequently of the growing dual facet of the States Parties' obligation to comply with the Court's judgments as an obligation of result and means, the Court's control of the application of Article 46 of the Convention is crucial».

There was a realisation that the Court had to place much more emphasis on tackling what Luzius Wildhaber, the former President of the Court, described as «structural dysfunction in the operation of legal system» [9, p. 29]. In the early 2000s, there were suggestions that these repetitive cases should be dealt with in a different way. There was an understanding that what was needed was a procedure «that focused less on giving individual justice... and more on the systemic and structural problems which were at the root of repetitive cases»».

In the case of Kudta v. Poland [GC], no. 30210/96, para. 148, ECHR 2000 XI the Court specified that the pilot judgment procedure was developed as a technique of identifying the structural/complex problems underlying repetitive cases against many countries and imposing an obligation on States to address those problems. In a pilot judgment, the Court's task is not only to decide whether a violation of the Convention occurred in the specific case but also to identify the systemic problem and to give the Government clear indications of the type of remedial measures needed to resolve it.

There are practical reasons why the Court issued such recommendations: (i) the Court has carefully examined the case and (ii) is in a very good position to make such proposals. However, the Court's jurisdiction in this field remains complementary. This means, first, that it is necessary to maintain the institutional balance under the 
Convention and, second, that States should be allowed certain latitude to decide upon and give effect to the most appropriate execution measures.

The Convention itself contains no provision expressly defining which categories of pronouncements can be in the operative part of a judgment. However, according to Rule 23 of the Practice Directions: Just Satisfaction claims (para. IV) [15] «only in extremely rare cases can the Court consider a consequential order aimed at putting an end or remedying the violation in question. The Court may, however, decide at its discretion to offer guidance for the execution of its judgment (Article 46 of the Convention).»

The Court usually refrains from making an «order» and instead normally only «recommends» or merely «indicates» which measures a respondent State ought to take in order to stop a violation. Since Gencel v. Turkey, the Court has, in cases concerning the fairness of proceedings under Article 6 of the Convention, suggested the reopening of the case in the domestic courts (if requested by the applicant). Numerous member States of the Council of Europe have introduced domestic machinery for requesting, on the basis of a finding by the Court of a violation of the Convention, the reexamination or reopening of a criminal case, which has been the subject of a final judicial decision. As regards the civil proceedings, after the CM Recommendation No. R (2000) 2, adopted on 19 January 2000, the reopening is possible in all member States (see, among others, detailed examination of this issue in the dissenting opinion of judge Pinto de Albuquerque joined by judges Karakaş, Sajó, Lazarova Trajkovska, Tsotsoria, Vehabović and Kūris in case of Moreira Ferreira v. Portugal (no. 2) [GC], no. 19867/12, judgment of 11.06.2017, §§ 32-39 and Gencel v. Turkey, no. 53431/99, § 27, 23, ECHR, October 2003).

Nevertheless, the Court has also gone further and urged, for example in Mandic and Jović v. Slovenia, nos. 5774/10 and 5985/10, para.124 et seq., 20 October 2011, ECHR 2011, that the respondent Government take steps to reduce the number of prisoners in a domestic prison. It has even apparently instructed States, for instance in Assanidze v. Georgia, no. 71503/01, para. 201 et seq., 8 April 2004, ECHR 2004-II and, Ilgar Mammadov v. Azerbaijan, no. 15172/13, ECHR 2014, Judgment of 22 May 2014, para.143 to release an applicant from prison.

Additionally, it should be stressed about the standard practice within the CM in cases where the Court remained silent on Article 46 of the Convention, the CM should require the respondent State to take general measures to avoid repetition of the violation(s) found. This suggestion is fully in line with the well-established role of the Committee of Ministers in the execution of judgments (these principles had been summarised by the Court itself in Scozzari and Giunta v. Italy [GC], nos. 39221/98 and 41963/98, judgment of 13 July 2007, § 249).

It should be pointed out that the pilot judgment procedure had initially been resisted by several governments, but had over time become politically acceptable [21, p. 84]. The Italian Government's position before the Grand Chamber case in the Sejdovic v. Italy, [GC], no. 56581/00, 1 March 2006 could confirm the resistance: «(...) the new practice pursued by the Court ran the risk of nullifying the principle that States were free to choose the means of executing judgments. It also ran counter to the spirit of the Convention and lacked a clear legal basis». The government added that «[i]n any event, if the practice of indicating general measures were to be continued, it should at least become institutionalised in the Rules of Court or in the questions which the Court put to the parties, so that the parties could submit observations on whether a violation was «systemic».

The division of power between the Court and the Committee of Ministers has evolved - particularly in the context of pilot judgment cases and other cases involving structural and/or systemic violations of the Convention - from a posture of passivity by 
Y. Sushko

ISSN 0136-8168. Вісник Львівського університету. Серія юридична. 2019. Випуск 68

the Court to one in which it is more proactive in its indication of non-monetary individual or general measures. However, it was not clear that the Court had adopted a coherent approach to this matter, especially in «quasi-pilot» cases or, even less, in ordinary cases, either at the level of a Chamber or the Grand Chamber.

The Court may interpret the Convention in a dynamic way, pressing forward, taking the lead - albeit in a methodologically sound way, i.e. by means of judicial arguments and within the limit that the Court's «normative innovation» must not go beyond what the State parties can, under the principle of bona fides, be assumed to have agreed to as the normative contents of the Convention [6, p. 56].

In its Position Paper of September 2003, the Court proposed the introduction of a «pilot judgment» procedure to be applied in «clone cases» dealing with systemic breakdown. It was suggested that a pilot judgment would trigger an accelerated execution procedure before the $\mathrm{CM}$ that would require the State not only to eliminate future violations, but also to provide domestic redress with retroactive effect (pars. 43-46) [19]. In 2004 as part of the reform's measures and in order to improve the execution of the Court judgments the CM adopted Resolution Res (2004) 3.

It could be said that the pilot judgment procedure was put in place subsequent to the adoption by the CM of Resolution Res (2004) 3 on «Judgments Revealing an Underling Systemic Problem» (adopted by the Committee of Ministers on 12 May 2004, at its 114th Session) and Recommendation Rec (2004) 6 on «The Improvement of Domestic Remedies» (adopted by the Committee of Ministers on 12 May 2004 at its 114th Session).

According to this Resolution Res(2004)3, the Court was invited: «as far as possible, to identify, in its judgments finding a violation of the Convention, what it considers to be an underlying systemic problem and the source of this problem, in particular when it is likely to give rise to numerous applications, so as to assist States in finding the appropriate solution and the Committee of Ministers in supervising the execution of judgments; to specially notify any judgment containing indications of the existence of a systemic problem and of the source of this problem (...), and to highlight such judgments in an appropriate manner in the database of the Court.»

In other words, the CM clearly encouraged the Court to be involved in the execution process in a proactive manner so as to better handle the issue of repetitive cases $[17, \mathrm{p}$. 239]. That Resolution, adopted at ministerial level, reflects the common position of all the Contracting Parties to the Convention. It should therefore be taken into account in the interpretation of the Convention.

In the CM Recommendation Rec (2004)6 (para. II) it was recommended to the Contracting States «to review, following Court judgments which point to structural or general deficiencies in national law or practice, the effectiveness of the existing domestic remedies and, where necessary, set up effective remedies, in order to avoid repetitive cases being brought before the Court.»)

Finally, the Court's competence to adopt pilot judgments derives from Article 46 of the Convention and is directed by Rule 61 par. 2 of the Rules of the Court. However, it should be mentioned that, at the fist stage, the Court has applied Article 41 of the Convention for this purpose, and only now the Court regularly applies Article 46 [3, p. 35]. The jurisprudence developed under Article 41 (that was initiated in the case of Papamichalopoulos and Others v. Greece (Article 50), no. 14556/89, 31.10.1995, paras. 34-40), in which the Court, for the first time, departed from the principle of the declaratory character of its judgments. Together with the usual declaration that the Convention was violated the Court went a step further and held in the operative part of the judgment that Greece was to return the land in issue to the applicants within six months. 
It could be assumed that the first pilot judgment was received favourably within the CoE's bodies. In its annual report of 2012 the CM positively remarked that the Court had engaged in assisting the execution process by giving clear indications since Assanidze case $[20$, p.16]. The Secretary General made the following statement in that regard: «the Court's innovative pilot judgment and similar procedures represent a very welcome development and should, if at all possible, now be made more transparent and systemic, if necessary by codification in the Convention, or in a future Statute of the Court, the better to ensure their effective operation in future» (para. 20) [5]. The Group of Wise Persons advised that pilot procedure should be used "as far as possible in future» [57, par. 105]. And finally, recently the positive effects of the pilot judgment procedure as a tool for improving national implementation of the Convention by tackling systemic or structural human rights problems has been confirmed during Copenhagen high-level Conference (para. 17) [22].

Since 2010, the Council of Europe has engaged in an ambitious reform process "to ensure the long term effectiveness of the Convention System.» The five High-level Conferences on reform of the Convention in Interlaken (2010), Izmir (2011), Brighton (2012), Brussels (2015) and Copenhagen (2018) addressed the main challenges such as the high number of applications made to the Court and the effective implementation of the Convention at national level. When the Interlaken process was initiated, the number of applications pending before the Court amounted to more than 140,000. Since then, the Court has managed to reduce this number considerably despite a continuous high number of new applications. This development testifies to the high ability of the Court to reform and streamline its working methods [8, p. 3-4].

Since the case of Marckx v. Belgium, no. 6833/74, Judgment of 13 June 1979, para.58, the Court has repeatedly held: «that its judgments are essentially declaratory in nature and that, in general, it is primarily for the State concerned to choose, subject to supervision by the Committee of Ministers, the means to be used in its domestic legal order in order to discharge its obligation under Article 46 of the Convention, provided that such means are compatible with the conclusions set out in the Court's judgment». This formula is said to reflect the principle of subsidiarity, which underpins the Convention system and according to which it is presumed that the national authorities are, in principle, better placed than the Court to identify and decide on implementing measures.

In the case of Papamichalopoulos and Others v. Greece, no. 14556/89, Judgment of 31 October 1995, para.34 the Court has stated that contracting States' freedom in choosing the means for fulfilling their primary obligation under Article 1 of the Convention to secure the rights and freedoms guaranteed under the Convention equally applies to the secondary obligations arising from a breach of the Convention.

The pilot judgment procedure is closely related to the interpretation of the Contracting State' obligations under the Convention. They are bound to fully adjust their domestic legal systems to the requirement deriving from the Convention, and to take comprehensive general measures of redress if a judgment has revealed that a violation was prompted be deficiencies in the implementation of the Convention. However, such an interpretation has already been recognized before the first pilot judgment; the Court has only emphasised these obligations particularly clearly in its pilot judgments. Therefore, it is possible to mark that the Court's interpretation of the Contracting States' obligations in its pilot judgments is not to be considered as an innovative approach [23, p. 292].

Consequently, it is possible to conclude that the introduction of the pilot procedure is an extension of the Court's practice of making recommendations. It should be noted that it only concerns a limited number of cases. However, it could be also noted that the 
Y. Sushko

ISSN 0136-8168. Вісник Львівського університету. Серія юридична. 2019. Випуск 68

Court exceeded the CM's request in Resolution Res (2004)3, which did not invite the Court to indicate remedial measures to be taken by the respondent State for the execution of the pilot judgments or to adjourn all «clone cases» [23, p. 28-29].

This procedure is a new way for the Court to deal with large-scale violations in an effective way. The idea behind it is the following: the Court chooses a test case and examines the reasons for the structural/complex problem in question and then renders a judgment in the case finding a violation. It normally gives the respondent State a time limit to correct the matter at the national level. Meanwhile, the Court adjourns the examination of similar cases until the Member State has retroactively taken the necessary general measures and the problem has been corrected. Thereafter, the cases still pending before the Court can be referred back to the national courts.

As it has been stressed by the Court in case of Kuric and others v. Slovenia [GC], no.26828/06, 26.06.2012, paras. 413-415 the main aims of the pilot judgment procedure are to facilitate effective implementation of its judgments and to allow the speediest possible redress to be granted at domestic level to the large numbers of people suffering from the general problem identified at the pilot judgment.

Before the first pilot judgment procedure was applied, remedial measures were left to the Member States. For example, after the judgment in case of Union Alimentaria Sanders S.A v. Spain, no. 11681/85, 07.07.1989, the Spanish authorities undertook significant judicial reform without any encouragement from the Court or the CM who only took note of the information (para. 4) [18]. In Bottazzi v.Italy [GC], no. 34884/97, 28.07.1999, para.22 the Court noted that breaches of the Convention reflected a continuous situation in respect of which there was no effective remedy.

The first mention of general measures by the Court was in the case Scozzari and Giunta v.Italy, nos. $39221 / 98$ and 41963/98, 13.07.2001, para. 249. For the first time the Court made reference to Article 46 of the Convention, stating that the responding state is also under obligation to put an end to the violation found by adopting, if appropriate, individual measures, along with adequate general measures. However, in this case no measures, general or individual were ordered or even recommended, but the case was used later as a reference case for numerous judgments where general measures were ordered (see as an example Emre v. Switzerland (No. 2), no. 5056/10, 11.10.2011, para. 67).

When indicating a specific measure, the Court should carefully assess whether the measures suggested are actually mandatory or whether they represent recommendations that the State may or may not follow. It must be pointed out that a State found to be in violation of the Convention has the secondary obligation to provide full reparation, which not only comprises the payment of the satisfaction awarded but also the adoption of individual and/or general measures if necessary. To that extent, the Court never imposes new obligations but only clarifies existing secondary obligations, the implementation of which might have caused problems either way [12, p. 841].

For the present days, the distinction between pilot and quasi-pilot judgment is not really clear. Both categories of judgments identify «structural/complex or systemic problems» or a «similar dysfunction of the system». The aim of both is the same assisting States and the CM in the execution process. These judgments offer the possibility of speedier redress to the individuals concerned and they help the Court to manage its workload. According to Rule 61 of the Rules of the Court (last amendments in April 2018), pertaining to the «pilot judgment procedure», the type of remedial measures which the Contracting Party concerned is required to take at the domestic level is identified «by virtue of the operative provisions of the judgment». However, analogous provisions can also be found in the operative part of other non-pilot judgment. The main 
distinction feature of a pilot judgment is that the Court adjourns other similar cases, which is not the case in quasi-pilot judgments.

Finally, the clearest difference between pilot and quasi-pilot judgments seems to be of a procedural rather that of a substantive nature - the parties are invited to comment upon the application of the pilot judgment procedure according to Rule 61 par.2 of the Rules of the Court which is not applicable to the quasi-pilot judgments [18, p. 287].

Nevertheless, this new Court's practice has not been without its critics even from the «insider of the Convention system», since it is not expressly enshrined in the Convention. In the Grand Chamber case of Hutten-Czapska v. Poland, no. 35014/97, 19.06.2006 Judge Zagrebelsky, who did not dispute the erga omnes effects of the Court judgments, was concerned that the "pilot judgment» method might upset the balance between the Court and the Committee of Ministers and make the mistake of shifting the Court on to the political terrain (particularly in the case in question, which involved a general measure that entailed an overhaul of property rights).

Regarding the present Court practice, certain researchers assume that the Court has self-authorized this development by unilaterally changing its role within the Convention implementation structure without solid contestation from the Convention States or the political organs of the CoE. However, this conclusion is rather shallow-minded.

Since the first pilot judgment Broniowski v. Pland [GC], no. 31443/96, 28.09.2005 (on the subject of properties situated beyond the Bug River - which concerned approximately 80,000 people) the Court has delivered thirty-five final pilot judgments, whereby it directed the Contracting States to take general measures in the interest of all existing and potential victims in order to resolve various dysfunctions in national human rights protection identified by the Court as «systemic/complex» or «structural» problems [1, p. 8].

Generally, there are more than 160 judgments of the Court (pilot or «quasi-pilot» and even ordinary judgments) [3, p. 169-170], which explicitly rely on Article 46 of the Convention in order to indicate the individual and/or general measures to be taken be the respondent State. The Court's backlog and the necessity to deal more efficiently with systemic problems, which produce numerous repetitive cases, constitute important factors in explaining this development [17, p. 236].

Most pilot judgments have been successfully implemented by means of general remedial measures introduced by the respondent States. Where such measures included a new legal remedy - compensatory or otherwise - capable of providing sufficient and adequate redress at domestic level, the Court declared the followup cases inadmissible for non-exhaustion of domestic remedies and «repatriated» them to the States in question (for example, see Nagovitsyn and Nalgiyev v. Russia (dec.), nos. 27451/09 and 60650/09, 23 September 2010; Latak v. Poland (dec.), no. 52070/08, 12 October 2010; Stella and 10 Others applications $v$. Italy (dec.), no. 49169/09, 16 September 2014).

Where the States introduced amending legislation providing existing and potential victims of a systemic violation with relief at domestic level such that the Court's further examination of similar applications was no longer justified, it struck those cases out of its list on the ground that the matter had been resolved, within the meaning of Article $37 \S 1$ (b) of the Convention, through the adoption of general measures, including compensatory remedies for redress with retrospective effect (see E.G. v. Poland and 175 Other Bug River applications v. Poland (dec.), no 50425/99, §§ 22-25, ECHR 2008 (extracts)). Additionally, three pilot-judgment procedures were formally closed by virtue of the Court's decisions following the implementation of general measures (See as an example Association of Real Property Owners in Łódź and Others v. Poland (dec.), no. 3485/02, ECHR 2011 (extracts); and Anastasov and Others v. Slovenia (dec.), no. 65020/13, 18 
October 2016.). However, taking into consideration the very wide terms of the recommendations made by the Court, and the fact that the Court normally acts on the basis of one case, the monitoring that it is able to do remains general in nature and should never lead the CM to close a case automatically.

It is important to distinguish between, on the one hand, remedial measures which the Court indicates in its reasoning in the form of recommendations, and, on the other hand, remedial measures inserted into the operative provisions. As regards the legal nature of such measures, there is a sort of «scale». There are «soft» recommendations that leave considerable latitude as to the content of the measures to be taken by the respondent State in the context of execution. There are also recommendations of a compelling nature, or indeed «targeted» recommendations - concerning measures, which are relatively precise. In some cases, especially in pilot judgments, the measure indicated by the Court appears in the operative part and is thus particularly mandatory. Such directions may be «soft» where they leave a wide margin to States as to the practical solution. On occasion, however, the directions are more forceful, leaving little or no freedom of choice to the respondent State [10, p. 19].

The legal dilemma could arise when, exceptionally, the Court prescribes individual or general measures in a judgment's operative provisions (as it did for example in cases Assanidze v. Georgia, no. 71503/01, judgment of 8 April 2004, Oleksandr Volkov v. Ukraine, no. 21722/11, judgment of 9 January 2013 and Grande Stevens and Others v. Italy, nos. 18640/10, 18647/10, judgment of 4 March 2014) as these provisions are the source of the legal obligation that attaches to the respondent State under Article 46 (2) of the Convention.

The Court's mandatory order fortifies the authority of the CM, thus increasing the pressure on the respondent Member States. The specificity of the Court's orders also facilitates the possibility that other political actors and the media will hold a violating government accountable concerning compliance. This consequently increases external pressure to effect implementation adequately and quickly.

The Judge Linos-Alexander Sicilianos, has stated that «if remedial measures are indicated, the nature, seriousness and/or persistence of the violation, the existence of an underlying structural problem, and the type and scale of the execution measure to be taken, are the main reasons for the differences in the prescriptiveness of the Court's indicated measures, which range from mildly worded general recommendations to the use of narrowly drawn and even strongly worded quasi-injunctive measures» [17, p. 236].

The other issue relates to the essence of the judicial function performed by the Court and its effect on the Court's remedial practice. The Court resolves disputes between applicants and the States based on the pleadings as formulated by the parties. The problem with the Court indicating specific remedial measures is that that issue has almost never been pleaded beforehand, at least not in normal Chamber or Grand Chamber cases (the exceptions are pilot judgment cases in which parties are invited to submit their observations upon the application of the pilot judgment procedure under Rule 61 (2) of the Rules of Court).

Recommending or ordering specific implementing measures, of course, does not guarantee that they will actually be adopted at the domestic level (such situation was analysed by the Court in Mukhitdinov v. Russia, no. 20999/14, judgment of 21 May $2015, \S \S 107-109$ and $\S \S 115-117$.). Yet clarity as to the precise obligations arising out of an adverse judgment may have positive effects on compliance. It has been shown, for instance, that the more clearly an obligation is formulated, the higher the political costs of not abiding by it are for a State [12, p. 840]. 
The Convention States appear to have intended to reject a direct effect of the Court judgments, as displayed in the travaux préparatoires. The Court was not meant to have the competence to annul, void or repeal national legal acts. This would, nevertheless, be the result in certain cases if the individual measures were to take direct legal effect. However, according to the living instrument doctrine, the Convention has to be interpreted in the light of today and if Convention States accepted the decisions and applied them directly, this would automatically indicate a change of intention.

The Court has repeatedly «emphasised that the Convention is a living instrument to be interpreted in the light of present-day conditions and this approach applies not only to the substantive rights protected under the Convention, but also to those provisions such as articles 25 and 46 which govern the operation of the Convention's enforcement machinery» $[14$, p. 10$]$.

It follows from the foregoing that the pilot judgments procedure, as well as quasipilot judgments procedure (which, being different in procedural methods applied by the Court, is not substantively different in the execution process), were a reaction to the structural human rights problems in Contracting States triggering repetitive applications and to several Contracting States' reluctance to solve those problems on the national level. Nevertheless, the Court still legally differs from an organ which is integrated into a Member State's domestic legal system and whose decisions take direct legal effect or an organ that has modifying powers, allowing it to call legislation void, overrule final judgments and annul executive acts.

Since the first pilot judgment the cooperation between the Court and the CM has definitely evolved from a posture of passivity by the Court to one in which it is more proactive in its indication of non-monetary individual or general measures. The traditional approach whereby the Court always rendered purely declaratory judgments and the Committee of Ministers had exclusive jurisdiction to supervise the execution of those judgments no longer corresponds to the current situation.

\section{Список використаних джерел}

1. Analysis of statistics of European Court of Human Rights (2018). - January 2019. [Electronic resource]. - Access mode : https://www.echr.coe.int/Documents/Stats_analysis_2018_ENG.pdf

2. Annual Report. European Court of Human Rights. - January 2019. [Electronic resource]. Access mode : https://www.echr.coe.int/Documents/Annual_report_2018_ENG.pdf

3. Binding effect and Declaratory nature of the judgments of the European Court of Human Rights: an overview // Mark E. Villiger; Judgments of the European Court of Human Rights : effects and implementation / Mark E. Villiger ; Anja Seibert-Fohr and Mark E. Villiger (eds.). - Baden-Baden: Nomos; [Farnham ; Burlington, Vt.] : Ashgate, 2014. - P. 35.

4. Committee of Ministers, $\mathrm{CM}(2006) 203$. Report of the Group of the Wise Persons to the Committee of Ministers, 15 November 2006, §105.

5. Council of Europe. Secretary General. Contribution of the Secretary General of the Council of Europe to the preparation of the Interlaken Ministerial Conference, SG/Inf(2009)20. [Electronic resource]. -Access mode : https://rm.coe.int/16805cff31

6. Cremer H.-J. Prescriptive Orders in the Operative Provisions of Judgments by the European Court of Human Rights: Beyond res judicanda? / Hans-Joachim Cremer // Anja Seibert-Fohr, Mark E. Villiger (Hrsg.), Judgments of the European Court of Human Rights - Effects and Implementation.

7. Drzemczewski A. The Parliamentary Assembly's Involvement in the Supervision of the Judgments of the Strasbourg Court, 28 Netherlands Quarterly of Human Rights, 2010. - № 2. - P. 164.

8. Evaluation of the effectiveness of the Council of Europe support to the implementation of the ECHR at national level, Abridged Final Report [Electronic resource]. // Evaluation (2017)20 published on 30 January 2017. - P. 16. - Access mode : https://rm.coe.int/16806f9221 
9. Hardman P. H. Responding to Systematic Human Rights Violations - An Analysis of 'Pilot Judgments' of the European Court of Human Rights and their Impact at National Level / Philip, Helen Hardman, Svetlana Stephenson and Brad K. Blitz // Greer, SC., 3 p. Common Market Law Review. 2011.

10. Implementation of the judgments of the European Court of Human Rights: a shared judicial responsibility? Dialogue between judges: Proceedings of the Seminar, European Court of Human Rights, Council of Europe. - 2014. - P. 40. [Electronic resource]. -Access mode : https://www.echr.coe.int/LibraryDocs/dialogueentre-juges-2014 eng.PDF

11. Jahn J., Ruling (In) directly through Individual Measures? Effect and Legitimacy of the ECtHR's New Remedial Power [Electronic resource]. / Jannika Jahn. - Access mode : http://www.zaoerv.de/74_2014/74_2014_1_a_1_40.pdf

12. Keller H. Reconceptualizing Implementation: The Judicialization of the Execution of the European Court of Human Rights' Judgments / Helen Keller and Cedric Marti // The European Journal of International Law. - 2016. - Vol. 26 no. 4. - P. 841.

13. Lamber Abdelgawad E. L'exécution des arrêts de la Cour européenne des sroits de l'homme (2010) / Lamber Abdelgawad E. // Revue trimestriell des droits de l'homme. - 2011. - P. 88, 939, 940-951.

14. Lambert H. The Position of Aliens in Relation to the European Convention on Human Rights / Hélène Lambert // Human rights files. - No. 8 (revised) Council of Europe Publishing. - P. 88.

15. Practice Directions: Just Satisfaction claims, available at https://www.echr.coe.int/Documents/PD_satisfaction_claims_ENG.pdf

16. Resolution of the CM Union Alimentaria Sanders S.A. [DH (90) 40]. [Electronic resource]. Access mode : http://hudoc.exec.coe.int

17. Sicilianos L.-A. The involvement of the European Court of Human Rights in the implementation of its judgments: recent developments under Article 46 ECHR / Linos-Alexandre Sicilianos // Netherlands quarterly of human rights. - Vol. 32, no. 3 (Sep. 2014). - P. 235-262.

18. Sicilianos L.-A. The role of the European Court of Human Rights in the execution of its own judgments: reflections on Article 46 ECHR, in Judgments of the European Court of Human Rights: effects and implementation / Linos-Alexandre Sicilianos ; Anja Seibert-Fohr and Mark E. Villiger (eds.). - Baden-Baden : Nomos; [Farnham; Burlington, Vt.]: Ashgate, 2014. - P. 285-315.

19. Steering Committee for Human Rights (CDDH). Position Paper of the European Court of Human Rights on proposals for reform of the European Convention of Human Rights and other measures as set out in the report of the Steering Committee for Human Rights of April 2003 (CDDH(2003)006 final), pars. 43-46. [Electronic resource]. - Access mode : https://search.coe.int/cm/Pages/result_details.aspx?ObjectId=09000016805e01c1

20. Supervision of the Execution of Judgments and Decisions of the European Court of Human Rights, 6th Annual Report of the CM 2012, at 28. - P. 169. [Electronic resource]. - Access mode : https://rm.coe.int/1680592ac8

21. The European Court of Human Rights' Remedial Practice and its Impact on the Execution of Judgments / Alice Donald and Anne-Katrin Speck // Human Rights Law Review. - February, 2019. - Vol. 19, Iss. 1. - P. 83-117.

22. The High Level Conference meeting in Copenhagen on 12 and 13 April 2018, Declaration, para. 17. [Electronic resource]. - Access mode : https://www.echr.coe.int/Documents/Copenhagen_Declaration_ENG.pdf

23. The Pilot-Judgment Procedure of the European Court of Human Rights, Author: Dominik Haider, Publication Date: 15 May 2013, ISBN: 978-90-04-24644-7.

\section{References}

1. Analysis of statistics of European Court of Human Rights (2018), January 2019. Retrieved from https://www.echr.coe.int/Documents/Stats_analysis_2018_ENG.pdf 
2. Annual Report. (2019). European Court of Human Rights. Retrieved from https://www.echr.coe.int/Documents/Annual_report_2018_ENG.pdf

3. Binding effect and Declaratory nature of the judgments of the European Court of Human Rights: an overview. (2014). In Mark E. Villiger; Judgments of the European Court of Human Rights: effects and implementation / Anja Seibert-Fohr and Mark E. Villiger (eds.). Baden-Baden: Nomos; [Farnham ; Burlington, Vt.].

4. Committee of Ministers (2006), CM(2006)203. Report of the Group of the Wise Persons to the Committee of Ministers, 15 November 2006.

5. Council of Europe. Secretary General. (2009). Contribution of the Secretary General of the Council of Europe to the preparation of the Interlaken Ministerial Conference, SG/Inf(2009)20. Retrieved from https://rm.coe.int/16805cff31

6. Cremer, H.-J. (2014). Prescriptive Orders in the Operative Provisions of Judgments by the European Court of Human Rights: Beyond res judicanda? in: Anja Seibert-Fohr, Mark E. Villiger (Hrsg.), Judgments of the European Court of Human Rights - Effects and Implementation.

7. Drzemczewski, A. (2010). The Parliamentary Assembly's Involvement in the Supervision of the Judgments of the Strasbourg Court. 28 Netherlands Quarterly of Human Rights 2, 164.

8. Evaluation of the effectiveness of the Council of Europe support to the implementation of the ECHR at national level. (2017). Abridged Final Report, Evaluation 20 published on 30 January 2017, 16. Retrieved from https://rm.coe.int/16806f9221

9. Hardman, P. H., Stephenson, S. and Blitz, B. K. (2011). Responding to Systematic Human Rights Violations - An Analysis of 'Pilot Judgments' of the European Court of Human Rights and their Impact at National Level./Greer, SC., 3 p. Common Market Law Review.

10. Implementation of the judgments of the European Court of Human Rights: a shared judicial responsibility? Dialogue between judges: Proceedings of the Seminar. (2014). European Court of Human Rights, Council of Europe, 40 Retrieved from https://www.echr.coe.int/LibraryDocs/dialogueentre-juges-2014_eng.PDF

11. Jahn, J. (2014). Ruling (In) directly through Individual Measures? Effect and Legitimacy of the ECtHR's New Remedial Power. Retrieved from http://www.zaoerv.de/74_2014/74_2014_1_a_1_40.pdf

12. Keller, H. and Marti, C. (2016). Reconceptualizing Implementation: The Judicialization of the Execution of the European Court of Human Rights' Judgments. The European Journal of International Law Vol. 26 no. 4, 841.

13. Lamber Abdelgawad, E. (2011). L'exécution des arrêts de la Cour européenne des sroits de l'homme. Revue trimestriell des droits de l'homme 88, 939, 940-951.

14. Lambert, H. (2007). The Position of Aliens in Relation to the European Convention on Human Rights, Human rights files, No. 8 (revised) Council of Europe Publishing, 88.

15. Practice Directions: Just Satisfaction claims. (2007). Retrieved from https://www.echr.coe.int/Documents/PD_satisfaction_claims_ENG.pdf

16. Resolution of the $\bar{C} M$ Union Alimentaria Sanders S.A. [DH (90) 40]. Retrieved from http://hudoc.exec.coe.int

17. Sicilianos, L.-A. (2014). The involvement of the European Court of Human Rights in the implementation of its judgments: recent developments under Article 46 ECHR, Netherlands quarterly of human rights, vol. 32, no. 3, 235-262.

18. Sicilianos, L.-A. (2014). The role of the European Court of Human Rights in the execution of its own judgments: reflections on Article 46 ECHR, in Judgments of the European Court of Human Rights: effects and implementation / Anja Seibert-Fohr and Mark E. Villiger (eds.). Baden-Baden: Nomos; [Farnham; Burlington, Vt.], 285-315.

19. Steering Committee for Human Rights (CDDH). (2003). Position Paper of the European Court of Human Rights on proposals for reform of the European Convention of Human 
Y. Sushko

ISSN 0136-8168. Вісник Львівського університету. Серія юридична. 2019. Випуск 68

Rights and other measures as set out in the report of the Steering Committee for Human Rights of April 2003 (CDDH(2003)006 final). Retrieved from https://search.coe.int/cm/Pages/result_details.aspx?ObjectId $=09000016805 \mathrm{e} 01 \mathrm{c} 1$

20. Supervision of the Execution of Judgments and Decisions of the European Court of Human Rights. (2012). 6th Annual Report of the CM, at 28, 169. Retrieved from https://rm.coe.int/$1680592 \mathrm{ac} 8$

21. Speck, A.-K., Donald A. (2019). The European Court of Human Rights' Remedial Practice and its Impact on the Execution of Judgments, Human Rights Law Review, vol. 19, Iss. 1, 83-117.

22. The High Level Conference meeting in Copenhagen on 12 and 13 April 2018. (2018) Declaration, para. 17. Retrieved from https://www.echr.coe.int/Documents/Copenhagen_Declaration_ENG.pdf

23. Haider, D. (2013). The Pilot-Judgment Procedure of the European Court of Human Rights, Leiden ; Boston : Martinus Nijhoff Publishers.

\title{
ПІЛОТНІ ТА КВАЗІПІЛОТНІ РІШЕННЯ СВРОПЕЙСЬКОГО СУДУ 3 ПРАВ ЛЮДИНИ: ЗАБЕЗПЕЧЕННЯ ПОСИЛЕНОГО ЗАХИСТУ ПРАВ ЛЮДИНИ
}

\author{
С. Сушко \\ Експерт проекту Ради Свропи \\ «Подальша підтримка реформи кримінальної юстиції в Україні», \\ e-mail:sushko12@gmail.com
}

Розширення Ради Європи та приєднання до неї нових членів у 90-х роках викликало значну кількість невирішених структурних проблем, які існували на той момент у нових Державах. Рада Європи та Європейський Суд зокрема, зіткнулися зі складними проблемами у функціонуванні цілих правових систем та їх невідповідністю вимогам Конвенції. Це спровокувало, як снігову лавину, завантаженість Суду однотипними справами, що своєю кількістю унеможливлювали чи зводили нанівець надання якісного правового захисту на Європейському рівні (наприклад, Суд розглянув більше 41000 справ, що стосувалися проблеми невиконання судових рушень в Україні). Зважаючи на прояви критики Суду з боку як Держав, так і заявників щодо тривалості розгляду справ, а також беручи до уваги повторюваність структурних проблем у Державах, Суд та інші органи Ради Європи вимушені були шукати швидкого та якісного вирішення цієї проблеми. Як Комітет Міністрів, який провадить нагляд за виконанням рішень Суду, так і сам Суд розробили низку нових механізмів для подолання структурних та повторюваних проблем у правових системах Держав. Суд почав впроваджувати практику прийняття пілотних, а в подальшому і квазіпілотних рішень, у яких він не тільки встановлював порушення Конвенції, а також фрормулював рекомендації, а іноді і зобов'язання, щодо вчинення конкретних загальних чи індивідуальних заходів під час виконання рішення. Дискусії щодо легітимності розширення таких повноважень Суду тривають досі, проте Держави толерують такі зміни у Конвенційній системі передусім зважаючи на їх необхідність та ефективність. Процедура пілотних судових рішень була відповіддю на структурні проблеми з правами людини в Договірних державах і відсутність політичної волі чи можливості Договірних Держав вирішувати ці проблеми на національному рівні самостійно.

На сьогоднішній день у спеціалізованій літературі порушено проблеми розмежування між пілотними та квазіпілотними рішеннями Суду та їх розуміння. Загалом основна відмінність між цими рішеннями полягає перш за все у процедурі їх ухвалення. Якщо Суд вирішує застосувати формальну пілотну процедуру у конкретній справі, то він інформує 
про це сторони, які в подальшому матимуть можливість надати коментарі в цій частині. Приймаючи пілотне рішення Суд, як правило, надає Державі певний строк для усунення недоліків та зупиняє розгляд інших типових справ. У той же час, у квазіпілотних рішеннях Суд не дає можливості коментувати сторонам це питання, практично ніколи не встановлює строків для вирішення структурної проблеми та не зупиняє розгляд інших типових справ.

Ключові слова: виконання рішень, клонові (однотипні) справи, комплексні та системні проблеми.

Стаття: надійшла до редакції 07.02.2019 прийнята до друку 21.05.2019 